\title{
The use of diffuse reflectance mid-infrared spectroscopy for the prediction of the concentration of chemical elements estimated by X-ray fluorescence in agricultural and grazing European soils
}

\author{
J.M. Soriano-Disla ${ }^{\mathrm{a}, \mathrm{b}, *}$, L. Janik ${ }^{\mathrm{a}}$, M.J. McLaughlin ${ }^{\mathrm{a}, \mathrm{c}}$, S. Forrester ${ }^{\mathrm{a}}$, J. Kirby ${ }^{\mathrm{a}}$, C. Reimann $^{\mathrm{d}}$, \\ The EuroGeoSurveys GEMAS Project Team ${ }^{1}$ \\ ${ }^{\text {a } C S I R O ~ S u s t a i n a b l e ~ A g r i c u l t u r e ~ F l a g s h i p ~ P r o g r a m, ~ C S I R O ~ L a n d ~ a n d ~ W a t e r, ~ P M B ~ 2, ~ G l e n ~ O s m o n d, ~ S o u t h ~ A u s t r a l i a ~ 5064, ~ A u s t r a l i a ~}$ \\ ${ }^{\mathrm{b}}$ Department of Agrochemistry and Environment, University Miguel Hernández of Elche, Avenida de la Universidad S/N, 03202 Elche, Spain \\ ' University of Adelaide, PMB 2, Glen Osmond, South Australia 5064, Australia \\ ${ }^{\mathrm{d}}$ Geological Survey of Norway, PO Box 6315, Sluppen, 7491 Trondheim, Norway
}

\section{A R T I C L E I N F O}

\section{Article history:}

Received 4 July 2012

Accepted 18 November 2012

Available online 29 November 2012

Editorial handling by R. Fuge

\begin{abstract}
A B S T R A C T
The aim of this study was to develop partial least-squares (PLS) regression models using diffuse reflectance Fourier transform mid-infrared (MIR) spectroscopy for the prediction of the concentration of elements in soil determined by X-ray fluorescence (XRF). A total of 4130 soils from the GEMAS European soil sampling program (geochemical mapping of agricultural soils and grazing land of Europe) were used for the development of models to predict concentrations of $\mathrm{Al}, \mathrm{As}, \mathrm{Ba}, \mathrm{Ca}, \mathrm{Ce}, \mathrm{Co}, \mathrm{Cr}, \mathrm{Cs}, \mathrm{Cu}, \mathrm{Fe}, \mathrm{Ga}, \mathrm{Hf}, \mathrm{K}, \mathrm{La}$, $\mathrm{Mg}, \mathrm{Mn}, \mathrm{Na}, \mathrm{Nb}, \mathrm{Ni}, \mathrm{P}, \mathrm{Pb}, \mathrm{Rb}, \mathrm{Sc}, \mathrm{Si}, \mathrm{Sr}, \mathrm{Th}, \mathrm{Ti}, \mathrm{V}, \mathrm{Y}, \mathrm{Zn}$ and $\mathrm{Zr}$ in soil using MIR spectroscopy. The results were compared with those obtained where MIR models were developed with the same soils but using the concentration of elements extracted with aqua regia (AR).

The PLS models were cross-validated against the experimental log-transformed XRF values of all the elements. The calibration models were derived from a set of 1000 randomly selected calibration samples. The rest of the samples (3130) were used as an independent validation set. According to the residual predictive deviation (RPD), predictions were classified as follows: "Good quality", $\mathrm{Ca}(2.9), \mathrm{Mg}(2.5), \mathrm{Al}(2.3)$, $\mathrm{Fe}$ (2.2), $\mathrm{Ga}$ (2.2), $\mathrm{Si}$ (2.1), $\mathrm{Na}$ (2.0); "Indicator quality", V (1.9), Ni (1.9), Sc (1.9), K (1.8), Ti (1.8), Rb (1.8), $\mathrm{Zn}$ (1.7), Co (1.7), Zr (1.6), Cr (1.6), Sr (1.6), Y (1.6), Nb (1.6), Ba (1.5), Mn (1.5), As (1.5), Ce (1.5); "Poor quality", Cs (1.4), Th (1.4), P (1.4), Cu (1.4), Pb (1.3), La (1.2), Hf (1.1).

Good agreement was observed between the RPD values obtained for the elements analysed in this study and those from the AR study. Despite the different elemental concentrations determined by the XRF method compared to the AR method, MIR spectroscopy was still capable of predicting elemental concentrations.
\end{abstract}

(c) 2012 Elsevier Ltd. All rights reserved.

\footnotetext{
* Corresponding author at: Department of Agrochemistry and Environment, University Miguel Hernández of Elche, Avenida de la Universidad S/N, 03202 Elche, Spain. Tel.: +61 883038425; fax: +61 883038572 .

E-mail address: jsoriano@umh.es (J.M. Soriano-Disla).

1 S. Albanese, M. Andersson, A. Arnoldussen, R. Baritz, M.J. Batista, A. Bel-lan, M. Birke, D. Cicchella, A. Demetriades, E. Dinelli, B. De Vivo, W. De Vos, R. Dohrmann, M Duris, A. Dusza-Dobek, O.A. Eggen, M. Eklund, V. Ernstsen, P. Filzmoser, T.E. Finne, D. Flight, M. Fuchs, U. Fugedi, A. Gilucis, M. Gosar, V. Gregorauskiene, A. Gulan, J. Halamid, E. Haslinger, P. Hayoz, G. Hobiger, R. Hoffmann, J. Hoogewerff, H. Hrvatovic S. Husnjak, C.C. Johnson, G. Jordan, J. Kivisilla, V. Klos, F. Krone, P. Kwecko, L. Kuti, A. Ladenberger, A. Lima, J. Locutura, P. Lucivjansky, D. Mackovych, B.I. Malyuk, R. Maquil, R.G. Meuli, N. Miosic, G. Mol, P. Négrel, P. O'Connor, K. Oorts, R.T. Ottesen, A. Pasieczna, V. Petersell, S. Pfleiderer, M. Poňavič, C. Prazeres, U. Rauch, I. Salpeteur, A Schedl, A. Scheib, I. Schoeters, P. Sefcik, E. Sellersjö, F. Skopljak, I. Slaninka, A. Šorša, R. Srvkota, T. Stafilov, T. Tarvainen, V. Trendavilov, P. Valera, V. Verougstraete, D. Vidojevid, A.M. Zissimos, Z. Zomeni.
}

\section{Introduction}

During the last two decades alternative cost-effective methods based on near-infrared (NIR) or mid-infrared (MIR) spectroscopy together with multivariate methods, including partial leastsquares (PLS) regression have been proposed for the prediction of elemental concentrations and soil properties, and to establish relationships between them (Janik et al., 1998; Reeves et al., 1999; McCarty et al., 2002; Brown et al., 2006). Predicted elemental concentrations can be used in studies of environmental and health risk assessment, environmental remediation, nutritional status, land management, organic amendments, geological surveys and soil mapping.

Both NIR (12,500-4000 $\left.\mathrm{cm}^{-1}\right)$ and MIR (4000-400 $\left.\mathrm{cm}^{-1}\right)$ spectra can be used for soil analysis, although it has been reported that, in general, better qualitative information is obtained in the MIR 